\title{
Preinduction Cervical Ripening with Prostaglandin E2 in Preterm Pregnancies
}

https://doi.org/10.32792/utq/utj/vol11/2/5

\author{
Aseel Mosa Jabber \\ M .SC .G .O. \\ The department of Obstetrics and Gynecology, Faculty of \\ Medicine Thi-Qar university
}

\begin{abstract}
Objective: This study evaluates efficacy of prostaglandin E2 (PGE2) for preinduction cervical ripening in preterm pregnancies, and to identify possible predictors of ripening failure.

Methods: Two groups of women admitted for induction of labor were included: Group $1(n=23)$ with preterm pregnancies and group $2(n=25)$, the control group, at term. The primary outcome measure was the result of cervical ripening. Cervical ripening was induced with successive administration of PGE2 vaginal tablets. After successful cervical ripening, augmentation of labor with oxytocin and/or artificial rupture of membranes are used if necessary.

Results: Ripening failure rate was higher in preterm group but not statistically significant $(\mathrm{p}=0.237)$. The overall caesarean section rate and the rate of caesarean section due to induction failure were significantly higher in preterm group than in term group. Ripening failure was inversely related to gestational age $(\mathrm{p}=0.008)$ even in the preterm group alone $(\mathrm{p}=0.007)$. The rate of 5-min Apgar score < 7 was comparable in both groups.

Conclusion: PGE2 is less effective for cervical ripening at preterm compared to term pregnancies. Lower gestational age was the only independent significant predictor of ripening failure.
\end{abstract}

Key Words: Preterm pregnancy - Cervical ripening - Prostaglandin E2. 


\section{اثر عقار بروستوكلاندين E2 في نضوج عنق الرحم للحوامل الخدج قبل البداء بتحفيز الولادة}

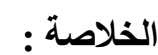

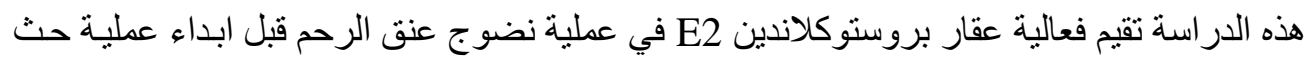

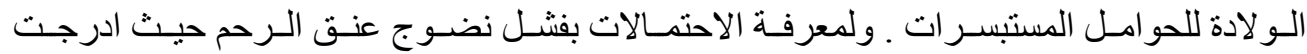

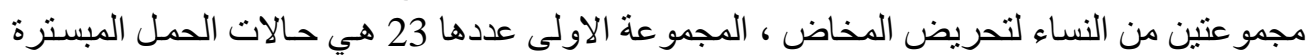

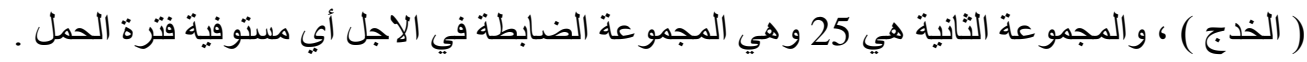

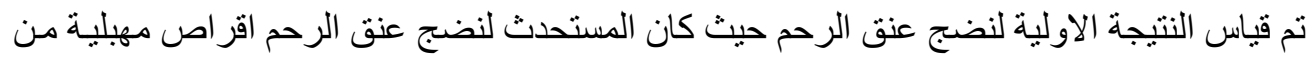

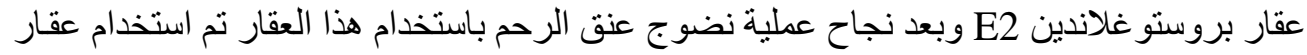

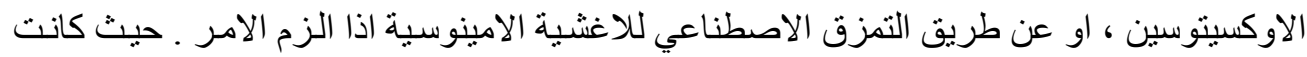

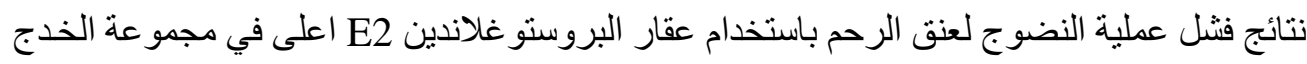

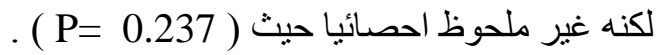

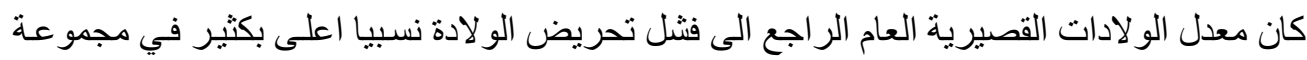

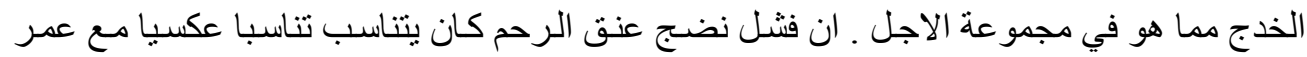

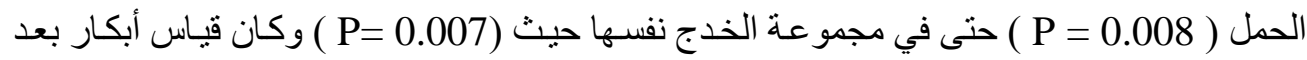

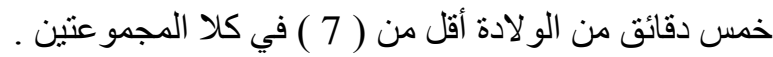

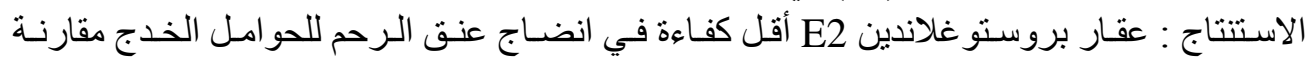
بالحوامل المكتملة الاجل ، حيث كان انخفاض عمر الحمل هو المؤشر المهم الوحيد في فنشل الانضاج

\section{Introduction}

Induction of labor in a patient with an unripe cervix is always a great challenge to the clinician. Ripening of the cervix governs the ease and success of induction of labor [1]. If ripening of the cervix fails to occur, then delivery and labor may be prolonged and may be unsuccessful [2].

Cesarean delivery rates are not necessarily higher in cases of elective induction, compared

with waiting until spontaneous labor, if the cervix is very favorable. However, cesarean deliveries are more common among nulliparas in the presence of an unfavorable cervix [3,4].

Cervical ripening in the presence of an unfavorable cervix can be undertaken using either pharmacological or mechanical methods. Examples of pharmacological methods that have undergone clinical investigation for cervical ripening include prostaglandins, RU 486 (mifepristone), estrogen, 


\section{University of Thi-Qar Journal Vol.11 No.2 June 2016}

Web Site: https://jutq.utq.edu.iq/index.php/main Email: journal@jutq.utq.edu.iq

and relaxin. Mechanical techniques include the intracervical insertion either of rubber catheters with balloons (i.e., a single or double balloon 16- French Foley catheter), osmotic dilators, or extra-amniotic infusion [5].

Prostaglandins have been administered orally, intravaginally, intracervically, or extra-amniotically to ripen the cervix and to initiate contractions. Application in the upper vagina or in the cervical canal is probably most desirable, because a lower total dose is necessary for the effect to be greater than a placebo [6].

The aim of this study was to evaluate the efficacy of prostaglandin E2 (PGE2) for preinduction cervical ripening in preterm pregnancies, and to identify possible predictors of ripening failure.

\section{Subjects and Methods}

The study included two groups of women ad-mitted for induction of labor in Obstetrics and Gynecology Department, Bent Al-Huda Teaching hospital and Al-Haboby Teaching Hospital and in a private center during the period from September 2013 to September 2015. They were recruited from those indicated for preinduction cervical ripening. Group $1(n=23)$ included women less than 37 weeks of gestation, while Group $2(n=25)$, the control group, included women at term. Exclusion criteria were multiple gestations, non- vertex presentation, previous caesarean section, placenta previa, congenital anomalies or any other contraindication for vaginal delivery.

After detailed explanation of the procedure all patients provided an informed consent before induction of labor. All cases received vaginal tablets of PGE2 for cervical ripening. Demographic data, indications for labor induction, baseline cervical condition, dose of PGE2 used and gestational age at delivery were recorded.

The primary outcome measure was the result of cervical ripening. Secondary outcome measures were mode of delivery, indications for caesarean section, and neonatal outcome. 
Table (1): Indications for labor induction in the two studied groups.

\begin{tabular}{|l|cl|cl|c|}
\hline \multicolumn{1}{|c|}{ Indication } & $\begin{array}{c}\text { Preterm Group } \\
(\mathbf{n = 2 3})\end{array}$ & $\begin{array}{c}\text { Term Group } \\
(\mathbf{n = 2 5})\end{array}$ & p value \\
\hline $\begin{array}{l}\text { Premature rupture of } \\
\text { membranes }\end{array}$ & 9 & $(39.1 \%)$ & 9 & $(45.0 \%)$ & 0.914 \\
\hline $\begin{array}{l}\text { Hypertensive disorders } \\
\text { Maternal medical } \\
\text { condition }\end{array}$ & $31(47.8 \%)$ & $14 \quad(56.0 \%)$ & 0.782 \\
\hline
\end{tabular}

Table (1) shows indications for induction of labor in the two groups. Hypertensive disorders include chronic hypertension, gestational hypertension, or preeclampsia. Maternal medical condition heart, renal, liver, lung, endocrine, autoimmune or neurological diseases. Large for gestational age is defined as estimated fetal weight $>90$ th percentile.

\section{Protocol of management:}

Cervical ripening was induced with successive administration of PGE2 vaginal tablets (Prostin E2 3mg, into the posterior fornix at 6-hour intervals for a maximum of 4 tablets. Fetal heart rate monitoring is performed prior to each application of PGE2 tablet. The end point was achievement of cervical ripening (Bishop score ${ }^{37}$ ), ripening failure (Bishop score $<7$ after 4 PGE2 tablets), or a maternal or fetal condition indicating immediate delivery. Following instillation of PGE2, the woman is advised to lie down for at least 40 minutes. Fetal heart rate monitoring was started after developing uterine contractions.

If patients experienced painful or frequent uterine contractions without sufficient cervical ripening, administration of the next PGE2 tablet was delayed until contractions subside in order to avoid uterine hyperstimulation; defined as fetal heart rate decelerations or fetal bradycardia in the presence of more than 5 uterine contractions in 10 minutes or 2 contractions lasting more than $2 \mathrm{~min}$.

After successful cervical ripening, augmentation of labor with oxytocin and/or artificial rupture of membranes are used if necessary. Fetal monitoring 


\section{University of Thi-Qar Journal Vol.11 No.2 June 2016}

Web Site: https://jutq.utq.edu.iq/index.php/main Email: journal@jutq.utq.edu.iq

continues till delivery. Oxytocin is given at an initial dose of $2.5 \mathrm{mU} / \mathrm{min}$, and the dose is incremented every $20 \mathrm{~min}$ as needed.

Failed induction is defined as a failure to reach a cervical dilatation $34 \mathrm{~cm}, 12$ hours after initiation of oxytocin infusion and/or artificial rupture of membranes.

\section{Statistical analysis:}

Data analysis was performed with the SPSS ver. 16. Mann-Whitney-test was used to compare continuous variables between the two groups, and Chisquare test was used for categorical variables. Multivariate logistic regression analysis was used to test independent predictors of ripening failure. A (p-value <0.05) was considered significant.

\section{Results}

The demographic and clinical characteristics of the two groups are shown in Table (2). Women in the preterm group presented with an apparently less favorable cervix but comparison did not show statistical significance (Table 2).

Ripening failure rate was higher in preterm group but not statistically significant. The overall caesarean section rate and the rate of caesarean section due to induction failure were significantly higher in preterm group than in term group. Ripening failure was inversely related to gestational age $(p=0.008)$ even in the preterm group alone $(p=0.007)$. The rate of 5 -min Apgar score $<7$ was comparable in both groups.

Table (2) : Demographic and clinical characteristics of the two studied groups .

\begin{tabular}{|l|c|c|c|}
\hline & $\begin{array}{c}\text { Preterm } \\
\text { Group } \\
(\mathbf{n = 2 3})\end{array}$ & $\begin{array}{c}\text { Term Group } \\
(\mathbf{n = 2 5})\end{array}$ & p value \\
\hline Age (years) & $29.2+3.6$ & $27.7+3.6$ & 0.168 \\
Nulliparity & $13(65.5 \%)$ & $16(56.0 \%)$ & 0.971 \\
\hline Cervical characteristics & & & \\
Dilatation $£ 1 \mathrm{~cm}$ & $5(21.7 \%)$ & $1(4.0 \%)$ & 0.091 \\
Effacement $<50 \%$ & $13(56.5 \%)$ & $16(64.0 \%)$ & 0.597 \\
\hline
\end{tabular}


University of Thi-Qar Journal Vol.11 No.2 June 2016

Web Site: https://jutq.utq.edu.iq/index.php/main Email: journal@jutq.utq.edu.iq

\begin{tabular}{|l|c|c|c|}
\hline Head station above -1 & $2(8.7 \%)$ & $1(4.0 \%)$ & 0.601 \\
GA at delivery (weeks) & $34.7+1.1$ & $38.9+1.6$ & $<0.001$ \\
\hline
\end{tabular}

$\mathrm{GA}=$ Gestational age

Table (3): Treatment results of the two studied groups.

\begin{tabular}{|l|c|c|c|}
\hline & $\begin{array}{c}\text { Preterm Group } \\
(\mathrm{n}=23)\end{array}$ & $\begin{array}{c}\text { Term Group } \\
(\mathrm{n}=25)\end{array}$ & $\mathrm{p}$ value \\
\hline Ripening failure rate & $5(21.7 \%)$ & $2(8.0 \%)$ & 0.237 \\
\hline Induction failure rate & $8(34.8 \%)$ & $2(8.0 \%)$ & 0.033 \\
\hline Response according to no. & & & \\
of tables : & $5(21.7 \%)$ & $6(24.0 \%)$ & \\
1 Tablet & $8(34.8 \%)$ & $9(36.0 \%)$ & \\
2 Tablets & $5(21.7 \%)$ & $4(16.0 \%)$ & \\
3 Tablets & 0 & $4(16.0 \%)$ & \\
4 Tablets & $78.3 \%$ & $76.0 \%$ & \\
\hline Cumulative success rate of & & & \\
treatment after 3 tablets & $78.3 \%$ & $92.0 \%$ & \\
\hline Cumulative success rate of & & & \\
treatment after 4 tablets & $1.42-2.58$ & $1.47-2.53$ & \\
\hline No. to tablets needed for & & & \\
ripening: & $13(56.5 \%)$ & $4(16.0 \%)$ & 0.009 \\
Median & $4(17.4 \%)$ & $3(12.0 \%)$ & $0.696 *$ \\
$95 \%$ CI & & & \\
\hline Overall Cesarean section \\
rate
\end{tabular}

$\mathrm{CI}=$ Confidence interval . * Fisher's exact test .

Table (4): Predictors of ripening failure.

\begin{tabular}{|l|c|c|c|}
\hline & $\begin{array}{c}\text { Ripening } \\
\text { failure } \\
(\mathrm{n}=7)\end{array}$ & $\begin{array}{c}\text { Ripening } \\
\text { success } \\
(\mathrm{n}=41)\end{array}$ & $\mathrm{p}$ value \\
\hline Maternal age & $30.4 \pm 4.5$ & $28.1 \pm 3.4$ & 0.249 \\
\hline Gestational age & $34.6 \pm 2.2$ & $37.3 \pm 2.4$ & 0.008 \\
\hline Nulliparity & $6(85.7 \%)$ & $23(56.1 \%)$ & 0.219 \\
\hline
\end{tabular}


University of Thi-Qar Journal Vol.11 No.2 June 2016

Web Site: https://jutq.utq.edu.iq/index.php/main Email: journal@jutq.utq.edu.iq

\begin{tabular}{|l|c|c|c|}
\hline Cervical dilatation & $1.7 \pm 0.5$ & $2.7 \pm 0.9$ & 0.009 \\
\hline Cervical effacement $<50 \%$ & $5(71.4 \%)$ & $24(58.5 \%)$ & 0.687 \\
\hline
\end{tabular}

On a multivariate logistic regression analysis, younger gestational age at delivery (Odds Ratio $=1.8,95 \%$ Confidence Interval: 1.0-3.1) was the only independent factor predicting failure of cervical ripening with PGE2.

Table (5) : Results of logistic regression analysis for prediction of ripening failure.

\begin{tabular}{|l|c|c|c|c|c|}
\hline & B & SE & p value & $\begin{array}{c}\text { Odds } \\
\text { Ratio } \\
(\text { OR })\end{array}$ & $\begin{array}{c}\text { 95\% CI } \\
\text { for OR }\end{array}$ \\
\hline GA & 0.564 & 0.282 & 0.045 & 1.8 & $1.0-3.1$ \\
\hline $\begin{array}{l}\text { Cervical } \\
\text { dilatation }\end{array}$ & 1.289 & 0.7000 & 0.066 & 3.6 & $0.9-14.3$ \\
\hline
\end{tabular}

\section{Discussion}

Exogenous prostaglandins induce cervical changes similar to physiologic cervical ripening in spontaneous labor. Dissolution of collagen, increase in glycosaminoglycans, and increase in fibroblast activity have been described in early gestation in humans and in late pregnancy in animals $[\mathbf{7 , 8}]$. Prostaglandins are known to enhance myometrial sensitivity to oxytocin. Ripening effects of prostaglandins may be followed by uterine contractions [9]. Prostaglandins have been reported to accelerate gap junction formation leading to more coordinated uterine contractions. Myometrial strips taken from the fundus of the uterus during spontaneous labor are stimulated by prostaglandin E2, although smooth muscle of the lower uterine segment and cervix is inhibited by prostaglandin E2 [10].

Several studies were published on the use of vaginal prostaglandin E2 for induction of labor at term. Kelly, et al. [11] reviewed 52 studies exam-ining 9402 women. They concluded that vaginal prostaglandin E2, compared with placebo or no treatment, reduced the likelihood of vaginal delivery not being achieved within 24 hours (18\% Vs. 99\%; RR 0.19; 95\% CI, 0.14-0.25). 


\section{University of Thi-Qar Journal Vol.11 No.2 June 2016}

Web Site: https://jutq.utq.edu.iq/index.php/main Email: journal@jutq.utq.edu.iq

Cesarean delivery rates were not different between groups, although the risk of uterine hyperstimulation with fetal heart rate changes was increased (4.6\% Vs. $0.51 \%$; RR 4.14; 95\% CI, 1.93-8.90) [11].

This study showed that the efficacy of PGE2 for cervical ripening at preterm is relatively lower than at term, as evidenced by the higher ripening failure rate and significantly higher induction failure rate in preterm group. The small number of cases might be the cause of lack of statistical significance in the rate of ripening failure. A higher number of PGE2 tablets seemed more effective at term reaching a cumulative success rate of $92 \%$, but statistically the difference was not significant. Lower gestational age was the only independent significant predictor of ripening failure.

Few reports are available on the use of PGE2 for cervical ripening at preterm. Abelin et al. [12] reported that the duration of labor was shorter and the need of oxytocin augmentation was less in preterm group compared to a term groups. They reported that heavy postpartum bleedings was a rare event. They confirmed safe vaginal labor induction and delivery in preterm pregnancy with intravaginal PGE2 gel. They noticed a five-fold higher risk of heavy postpartum bleeding in the post-term group compared to the pre-term in their series.

A randomized prospective study 13 compared the use of intravenous oxytocin with oral PGE2 tablets for stimulation of labor in cases of preterm premature rupture of membranes. Labor induction was successful in $96 \%$ of patients in the PGE2 group compared with $84 \%$ in the oxytocin group. The incidence of cesarean section (CS) was 5\% and 16\% in the PGE2 and the oxytocin groups, respectively.

Another case-control study of preterm pregnancies 24 and 36 weeks gestation, reported that vaginal PGE2 gel improved Bishop score without labor $50 \%$ of cases. It leads to non-significant reduction of cesarean delivery rate to $45 \%$ versus $68 \%$ in the control group [14].

Sien ko, et al. [15] conducted a retrospective study of 22 preterm deliveries using endocervical PGE2 gel versus a control group consisted of 26 pregnancies at term. They found no differences in the incidence of cesarean sections, characteristics of indications of operative delivery, duration of particular stages of labor and estimated blood loss.

A recent large retrospective study [16] involving 444 women using PGE2 vaginal tablets to induce cervical ripening at preterm concluded that ripening 


\section{University of Thi-Qar Journal Vol.11 No.2 June 2016}

Web Site: https://jutq.utq.edu.iq/index.php/main Email: journal@jutq.utq.edu.iq

failure and caesarean section were more common in preterm compared with term gestations. Women at preterm required a significantly higher number of PGE2 tablets compared to women at term.

Unfavorable cervix was confirmed as a common cause of failed labor induction at preterm $[\mathbf{1 7 , 1 8}]$. In a study on pregnant baboon cervix, expression of the gene encoding the prostanoid EP1 receptor increased with advancing gestational age prior to labor [19]. This was supported by a more recent human study reporting that expression of the pros-tanoid EP2 receptor mRNA was inversely related to gestational age [20].

We found PGE2 vaginal tablets safe for the mother and neonate. No uterine hyperstimulation or neonatal complications were recorded. This finding is in agreement with previous reports [12-14,21].

Previous studies reported that nulliparity, advanced maternal age [22,23], and unfavorable cervical score [23] are independent predictors of failed induction. These two studies included only term pregnancies.

We can conclude that PGE2 is less effective for cervical ripening at preterm compared to term pregnancies. Lower gestational age was the only independent significant predictor of ripening failure.

\section{References}

1- CALDER A.A., EMBREY M.P. and TAIT T.: Ripening of the cervix with extra-amniotic prostaglandin E2 in viscous gel before induction of labor. Br. J. Obstet. Gynecol., 84 (4): 264-8, 1977.

2- PRINS R.P., BOLTON R.N., MARK C.3rd., NEILSON D.R. and WATSON P.: cervical ripening with intravaginal prostaglandin E2 gel. Obstet. Gynecol. Apr., 61 (4): 459- 62, 1983.

3- YEAST J.D., JONES A. and POSKIN M. (1999): Induction of labor and the relationship to cesarian delivery: A review of 7001 consecutive inductions. Am. J. Obstet. Gynecol., 180: 628-33, 1983.

4- DUBLIN S., LYDON-ROCHELLE M. and KAPLAN R.C. et al.: Maternal and neonatal outcomes after induction of labor without an identified indication. Am. J. Obstet. Gynecol., 183: 986-94, 2000. 


\section{University of Thi-Qar Journal Vol.11 No.2 June 2016}

Web Site: https://jutq.utq.edu.iq/index.php/main Email: journal@jutq.utq.edu.iq

5- RAYBURN W.F.: Preinduction cervical ripening: Basis and methods of current practice. Obstet. Gynecol. Surv., 57 (10): 683-92, 2000.

6- KERISE M.: Prostaglandin in preinduction cervical ripening: Metaanalysis of worldwide clinical experience. J. Reprod Med., 38: 89-94, 1993.

7- ULDBJERG N., EKMAN G., MALMSTRON A., et al.: Biochemical and morphological changes of human cervix after local application of prostaglandin E2 in pregnancy. Lancet, 2: 267-72, 1981.

8- RAYBURN W., LIGHTFOOT S., NEWLAND J., et al.: A model for investigating microscopic changes induced by prostaglandin E2 in the term cervix. J. Maternal Fetal Invest, 4: 137-40, 1994.

9- MILLER A.M., RAYBURN W.F. and SMITH C.V.: Pat-terns of uterine activity after intravaginal prostaglandin E2 during preinduction cervical ripening. Am. J. Obstet. Gynecol., 165: 1006-10, 1991.

10- WIKLAND M., LINDBLOM B. and WIQUIST N.: Myometrial response to prostaglandins during labor. Gynecol. Obstet. Invest, 17: 131-6, 1984.

11- KELLY A.J., KAVANAGH J. and THOMAS J.: Vaginal prostaglandin (PGE2 and PGF2) for induction of labor at term (Cochrane Review). In: The Cochrane Library, Issue 4, Oxford: Update Software, 2001.

12- ABELIN TORNBLOM S., OSTLUND E., GRANSTROM L. and EKMAN G.: Pre-term cervical ripening and labor induction. Eur. J. Obstet. Gynecol. Repord Biol., 10; 104 (2): 120-3, 2002.

13- EL-QARMALAWI A.M., ELMARDI A.A., SADDIK M., EL-ABDEL HADI F. and SHAKER S.M.: A comparative randomized study of oral prostaglandin E2 (PGE2) tablets and intravenous oxytocin in induction of labor in patients with premature rupture of membranes before 37 weeks of pregnancy. Int. J. Obstet. Gynecol., 33 (2): 115-9, 1990.

14- CARLAN S.J., O'BRIEN W.F. and LOGAN S.: Serial intravaginal prostaglandin E2 gel cervical ripening in Preterm Pregnancies. Prostaglandins, 52 (3): 237-46, 1996.

15- SIENKO J., CZAJKOWSKI K., NOWAK R., BROS M., KUNICKI M. and STRZYZEWSKI W.: Prostaglandin E2 gel for labor induction in preterm pregnancy. Med. Wieku Rozwoj, (3 Suppl 1): 301-5, 2009. 
16-MELAMED N., YOGEV Y., HADAR E., HOD M. and BENHAROUSH A.: preinduction cervical ripening with prostaglandin E2 at pretem. Acta. Obstet. Gynecol. Scand, 87 (1): 63-7, 2012.

17- KARAISKAKIS P.T., RAYBURN W.F., SMITH C.V. and WOODS R.E.: Failed induction of labor despite sequential prostaglandin E2 therapy. Am. J. Perinatol., 8 (2): 128- 30, 1991.

18- CALISKAN E., DIBLAZ S., GELISEN O., DIBLAZ B., OZTURK N. and HABERAL A.: Unsucessful labor in-duction in women with unfavourable cervical scores: predictors and management. Aust. N Z J. Obstet. Gynecol., 44 (6): 562-7, 2009.

19- SMITH G.C., WU W.X. and NATHANIELSZ P.W.: Effects of gestational age and labor on the expression of prostanoid receptors genes in pregnant baboon cervix. Prostaglandins, Mar., 63 (4): 153163, 2001.

20- LEONHARDT A., GLASER A., WEGMANN M., HACK-ENBERG R. and NUSING R.M.: Expression of prostanoid receptors in human lower segment pregnant myometrium. Prostaglandins Leukot Essent Fatty Acids, 69 (5): 307- 13, 2013.

21- MILLIEZ J.M., JANNET D., TOUBOUL C. EL MEDJ-ADJI M. and PANIEL B.J.: Maturation of uterine cervix by repeated intracervical instillation of prostaglandin E2. Am. J. Obstet. Gynecol., 165 (3): 5238, 1997.

22- PRYSAK M. and CASTRONOVA F.C.: Elective induction versus spontaneous labor: A case-control analysis of safety and efficacy. Obstet. Gynecol., 92 (1): 47-52, 2002.

23- YOGEV Y., BEN-HAROUSH A., GILBOA Y., CHEN R., KAPLAN B. and HOD M.: Induction of labor with vaginal prostaglandin E2. J. Matern Fetal Neonatal Med., 14 (1): 30-4, 2013. 